\title{
Dual Response of Human Leukemia U937 Cells to Hypertonic Shrinkage: Initial Regulatory Volume Increase (RVI) and Delayed Apoptotic Volume Decrease (AVD)
}

\author{
Valentina E. Yurinskaya Alexey V. Moshkov Anna V. Wibberley Florian Lang ${ }^{a}$ \\ Michael A. Model ${ }^{\mathrm{b}}$ Alexey A. Vereninov \\ Laboratory of Cell Physiology, Institute of Cytology, Russian Academy of Sciences, St-Petersburg;

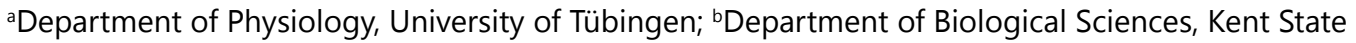 \\ University, Kent, Ohio
}

\section{Key Words}

Apoptosis $\cdot$ Cell volume regulation $•$ Osmotic stress

\begin{abstract}
Background/Aims: Osmotic cell shrinkage is a powerful trigger of suicidal cell death or apoptosis, which is paralleled and enforced by apoptotic volume decrease (AVD). Cells counteract cell shrinkage by volume regulatory increase (RVI). The present study explored the response of human U937 cells to hypertonic solution thus elucidating the relationship between RVI and AVD. Methods: Cell water, concentration of monovalent ions and the appearance of apoptotic markers were followed for $0.5-4 \mathrm{~h}$ after the cells were transferred to a hypertonic medium. Intracellular water, $\mathrm{K}^{+}, \mathrm{Na}^{+}$, and $\mathrm{Cl}^{-}$content, ouabain-sensitive and -resistant $\mathrm{Rb}^{+}$influxes were determined by measurement of the cell buoyant density in Percoll density gradient, flame emission analysis and ${ }^{36} \mathrm{Cl}^{-}$assay, respectively. Fluorescent microscopy of live cells stained by acridine orange and ethidium bromide was used to verify apoptosis. Results: After 2-4 h incubation in hypertonic media the cell population was split into light $(\mathrm{L})$ and heavy $(\mathrm{H})$ fractions. According to microscopy and analysis of monovalent ions the majority of cells in the $L$ population were healthy, while the $\mathrm{H}$ fractions were enriched with apoptotic cells. The density of $L$ cells was decreasing with time, while the density of $\mathrm{H}$ cells was increasing, thus reflecting the opposite effects of RVI and AVD. At the same time, some of the cells were shifting from $L$ to $H$ fractions, indicating that apoptosis was gradually extending to cells that were previously displaying normal RVI. Conclusion: The findings suggest that apoptosis can develop in cells capable of RVI.
\end{abstract}




\section{Introduction}

In a wide variety of cell types, hypertonic cell shrinkage results in apoptosis [1-18]. A distinctive feature of apoptosis is the apoptotic volume decrease (AVD), i.e. a decrease in cell volume generated by an intrinsic apoptotic machinery and associated with specific changes in the monovalent ion fluxes and content $[1,7,19-26]$. On the other hand, hypertonic shrinkage triggers regulatory volume increase (RVI), a common response of cells to water balance disturbance $[12,27]$. The relationship between AVD and RVI provides additional insights into the physiology of apoptosis. It has been hypothesized that impairment of cell volume regulation plays a significant role in initiating apoptosis and AVD [20, 25]. We have previously reported that hypertonic shrinkage of human leukemic cells U937 initially caused RVI that was later superseded by the AVD response [28]. Accordingly, AVD and apoptosis may be triggered in cells which are still capable of RVI. The present study explored RVI and AVD in U937 cells in response to hypertonic shrinkage in greater detail. The question of how the same initial perturbation causes physically opposite physiological responses, is of importance beyond its relevance to apoptosis. U937 cells treated by hypertonic solution may thus be a useful model to study the switching of intracellular volume regulatory mechanisms from RVI to AVD.

\section{Materials and Methods}

\section{Reagents}

RPMI 1640 medium and fetal bovine serum (FBS, HyClone Standard) were purchased from Biolot (Saint Petersburg, Russia). Ouabain, 5-(N,N-dimethyl)-amiloride (DMA), 4,4-diisothiocyanatostilbene-2,2disulfonic acid (DIDS) were purchased from Sigma-Aldrich (Steinheim, Germany). Stock solutions of DMA (10 mM in DMSO), ouabain (1 mM in phosphate salt buffer solution PBS) and DIDS (20 mM in water) were stored at $4{ }^{\circ} \mathrm{C}$. Percoll was from Pharmacia (Uppsala, Sweden). Acridine orange (AO) and ethidium bromide (EB) were from Serva (Heidelberg, Germany). The isotope ${ }^{36} \mathrm{Cl}^{-}$was from "Isotope" (Saint Petersburg, Russia). Sucrose of analytical grade was from Reachem (Saint Petersburg, Russia).

\section{Cell cultures and media}

Human histiocytic lymphoma U937 cells from the German Collection of Microorganisms and Cell Cultures (DSMZ) were maintained in RPMI 1640 medium with $10 \%$ fetal bovine serum at $37{ }^{\circ} \mathrm{C}$ and $5 \% \mathrm{CO}_{2}$. The experiments were performed on cells from one unfrozen batch cultured for 4-12 passages. Cells were plated at a density of (1-1.5) $\times 10^{6}$ cells per ml. The hypertonic media were prepared by addition of $100 \mathrm{mM}$ $\mathrm{NaCl}$ or $150-300 \mathrm{mM}$ sucrose to the isotonic RPMI medium. All the incubations were done at $37^{\circ} \mathrm{C}$.

\section{Determination of cell water content and cell volume}

Cell water was determined by measurements of the buoyant density of cells in continuous Percoll gradient as described earlier [29, 30]. The osmolarity of Percoll solution was changed by adding $100 \mathrm{mM}$ $\mathrm{NaCl}$ or 150-300 mM sucrose and checked with the Advanced Instruments Micro-osmometer Model 3320. The buoyant density of cells was estimated using density marker beads (DMB, Sigma-Aldrich, Germany). For the values of density of DMB in sucrose-containing Percoll medium manufacturer's data additionally confirmed by gravimetric measurements were used. After the cells achieved isopycnic distribution in a density gradient, fractions were collected, washed with RPMI and assayed for ion content. The buoyant density of cells proved to be a more sensitive and reliable measure of cell water content than techniques based on comparison of intra- and extracellular water marker distribution. A difference of buoyant density by $0.005 \mathrm{~g} \mathrm{ml}^{-1}$, which corresponds to a $10 \%$ change in cell water content per $\mathrm{g}$ of cell protein, yields a displacement of cells in gradient tubes by about $1 \mathrm{~cm}$. The water content per $g$ of protein, $v_{\text {prot }}$, was calculated as $v_{\text {prot. }}=\left(1-\rho / \rho_{\text {dry }}\right) /[0.79(\rho-1)]$, where $\rho$ is the measured buoyant density of the cells and $\rho_{\text {dry }}$ is the cell dry mass density; the latter was estimated as $1.35 \mathrm{~g} \mathrm{ml}^{-1}[30]$. Cell volume per $\mathrm{g}$ of protein was calculated as vol $_{\text {prot }}=\left(1-\rho / \rho_{\text {dry }}\right) /[0.79(\rho-1)]+1 / 0.79 \rho_{\text {dry }}$. 
Determination of intracellular ion content and $R b^{+}$influx

Intracellular content of $\mathrm{K}^{+}, \mathrm{Na}^{+}$and $\mathrm{Rb}^{+}$ions was assayed by flame emission spectrometry with a Perkin-Elmer AA 306 spectrophotometer, as described previously [29]. $\mathrm{Rb}^{+}$influx was determined after cell fractionation in the density gradient by adding $2.5 \mathrm{mM} \mathrm{RbCl}$ to the medium for $10 \mathrm{~min} . \mathrm{Rb}^{+}$influx via $\mathrm{Na}^{+}$/ $\mathrm{K}^{+}$pump was evaluated from the difference between $\mathrm{Rb}^{+}$uptake in the presence and absence of $0.1 \mathrm{mM}$ ouabain. To determine intracellular $\mathrm{Cl}^{-}$, cells were cultured for $\geq 90 \mathrm{~min}$ at $37^{\circ} \mathrm{C}$ in RPMI medium containing ${ }^{36} \mathrm{Cl}^{-}\left(0.12 \mu \mathrm{Ci} \mathrm{ml}^{-1}\right)$. The radioactivity of ${ }^{36} \mathrm{Cl}^{-}$was measured using a liquid scintillation counter (Beckman LS 6500), and the intracellular $\mathrm{Cl}^{-}$content was calculated based on the specific activity of ${ }^{36} \mathrm{Cl}^{-}(\sim 2$ counts $\min ^{-1} \mu \mathrm{mol}^{-1}$ ). Cell protein was analyzed by the Lowry method with serum bovine albumin as a standard.

\section{Microscopy}

Living cells stained with acridine orange (AO, $10 \mu \mathrm{g} / \mathrm{ml}$ ) and ethidium bromide (EB, $20 \mu \mathrm{g} / \mathrm{ml}$ ) for 15-20 min were observed under a Leica TCS SL confocal microscope with excitation lasers 488 and $532 \mathrm{~nm}$. Fluorescence was registered at 500-550 and 600-700 nm. Transmission images of cells in culture plates were obtained on an Axiovert 200M microscope equipped with a digital camera Leica DFC 420. Image analysis was performed using ImageJ 1.43(http://rsbweb.nih.gov/ij/).

Statistical analysis

The results were statistically analyzed using Student's t-test. Differences were considered to be significant at $\mathrm{p}<0.05$.

\section{Results}

Cell buoyant density, cell water

Exposure of cells to hypertonic medium was followed by a prompt increase in cell buoyant density due to passive osmotic loss of cell water. The observed changes in cell density corresponded to a loss of cell water by 38-56\% (depending on the osmolarity of the medium), i.e. to a decrease in the cell volume by $32-47 \%$ (Fig. $1 A-D$ ). Cells that shrank in hypertonic media initially formed a single band in the Percoll gradient that occupied a density interval of about $0.012 \mathrm{mg} \mathrm{ml}^{-1}$. Following 2-3 $\mathrm{h}$ incubation, the cell population appeared to split into two subpopulations separated by a clearly detectable gap. Cell density in the light subpopulation (L) decreased relative to the density at time point $0.5 \mathrm{~h}$, whereas the density of cells in the heavy subpopulation (H) slowly increased.

The ratio of $\mathrm{H}$ to $\mathrm{L}$ cell numbers (estimated by protein) increased over time, and by $4 \mathrm{~h} \mathrm{H}$ cells comprised $50-60 \%$ of the total population (Fig. $1 L, M$ ). Accordingly, cells initially responded by RVI, but later started to shrink and shifted to the $\mathrm{H}$ fraction; this transition appeared to happen rather fast. The cell volume increase following the initial hypertonic cell shrinkage should be interpreted as an RVI. About $80-90 \%$ of U937 cells were able to increase their cell water content by $10.8-17.4 \%$ (corresponding to an $8.5-13.2 \%$ volume increase) within $2 \mathrm{~h}$ relative to its lowest value at $0.5 \mathrm{~h}$ (without reaching the initial value in normotonic medium). Different cell types vary in their ability to restore their volume in hypertonic solutions. In some cells, RVI response is only observed when cells preincubated in hypotonic medium are returned to isotonic solution [27,31]. Some cells are able to restore their volume more effectively than U937 cells [11, 32, 33]. Nevertheless, the present data reveal the ability of U937 cells to mount a partial RVI in response to direct transition from normotonic to hypertonic media.

\section{Monovalent ions}

The increase in cell hydration responsible for RVI was associated with an increase in cell $\mathrm{K}^{+}$and $\mathrm{Cl}^{-}$content (Fig. $1 E$ - $H$, Fig. 2, Table 1). In turn, a decrease in cell water in $\mathrm{H}$ subpopulation was associated with a decrease in cell $\mathrm{K}^{+}$and an increase in $\mathrm{Na}^{+}$. A decrease in $\mathrm{Cl}^{-}$content was observed in the unfractionated cell population $4 \mathrm{~h}$ following hypertonic exposure, when the proportion of heavy cells was significant (Fig. 2). A decrease in $\mathrm{Cl}^{-}$and 


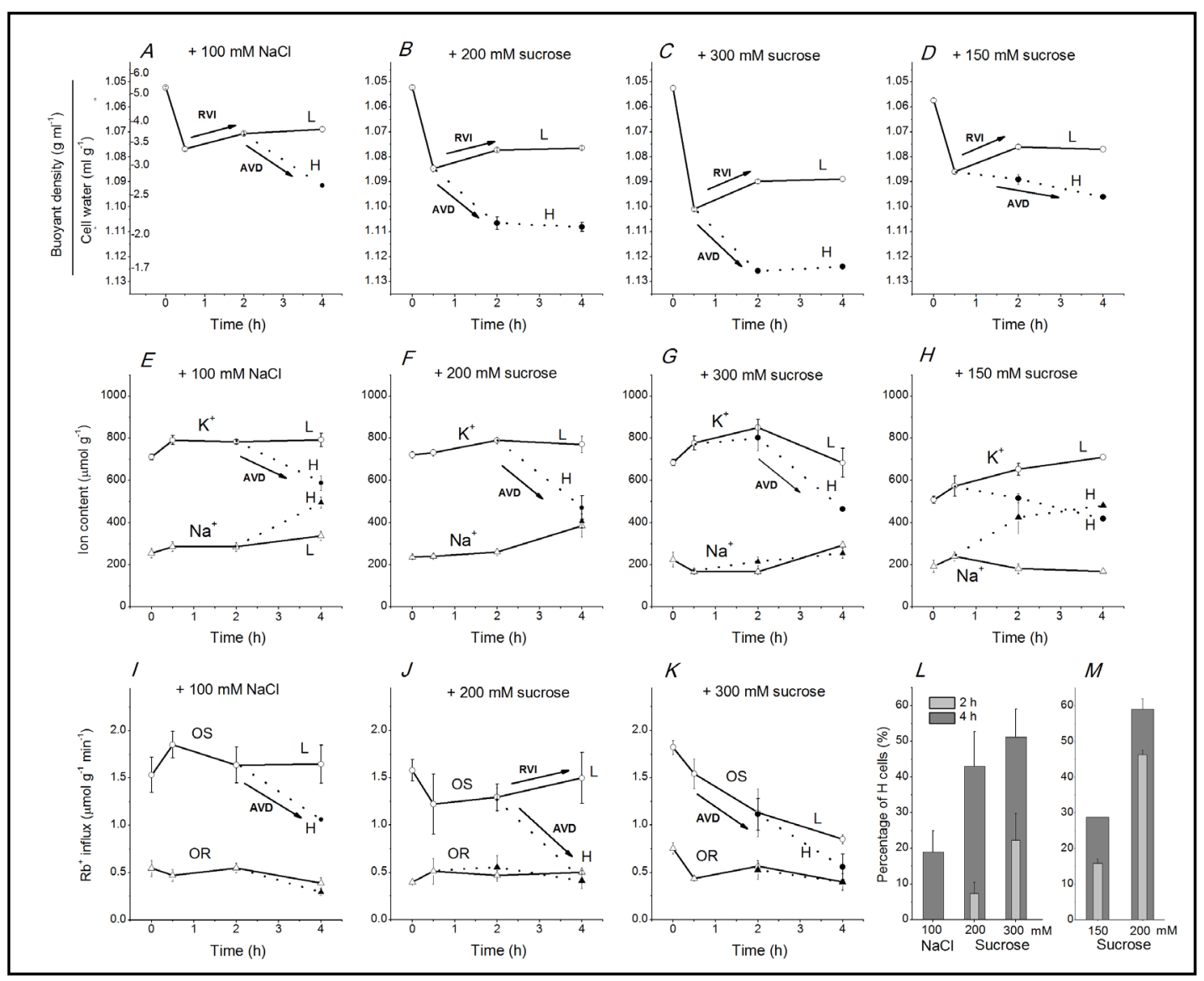

Fig. 1. Effect of hypertonic media on cellular characteristics. $(A-D)$ Cell buoyant density and cell water content. Solid lines indicate unfractionated cells or light $(\mathrm{K})$ cell subpopulation; dotted lines, heavy $(\mathrm{H})$ cell subpopulation. $(E-H)$ Intracellular $\mathrm{K}^{+}$and $\mathrm{Na}^{+}$content. $(I-K)$ Ouabain-sensitive (OS) and -resistant (OR) $\mathrm{Rb}^{+}$influxes. $(L, M)$ Percentages of cells in $\mathrm{L}$ and $\mathrm{H}$ fractions (estimated by protein) following $2 \mathrm{~h}$ and $4 \mathrm{~h}$ incubations in hypertonic media. Data at time zero represent cells in normal RPMI medium. The means \pm SEM were calculated from $\geq 3$ independent experiments (except for the $4 \mathrm{~h}$ point in $150 \mathrm{mM}$ sucrose, which was tested only once). The data in panels $D, H$ and $M$ were obtained in different series of experiments than the data in the rest of the other panels.

$\mathrm{K}^{+}$content, as well as an increase in $\mathrm{Na}^{+}$content, has been previously observed in U937 cells where apoptosis was induced, in particular, by staurosporine [26]; thus, the ion composition of the $\mathrm{H}$ subpopulation is clearly indicative of apoptosis.

The data presented in Table 1 allow semi-quantitative estimates of the contribution of monovalent ions to the total increase of cellular osmolytes responsible for RVI. Table 1 shows that within $2 \mathrm{~h}$ of hypertonic challenge one third to one half of the increase in total intracellular osmolarity was due to $\mathrm{K}^{+}$and about $3 / 4$ due to the sum of $\mathrm{K}^{+}$and $\mathrm{Cl}^{-}$. The impact of the changes in $\mathrm{Na}^{+}$content at this time point was small and not identical in different experiments.

\section{DMA+DIDS effect}

The RVI response was abolished by DMA+DIDS (DD) used to block the hypertonicityinduced cation channels (HICC) and $\mathrm{Na}^{+} / \mathrm{H}^{+}$and $\mathrm{Cl}^{-} / \mathrm{HCO}_{3}^{-}$exchangers that are considered key players in RVI in many cell types [27, 33-37]. Indeed, U937 cells incubated in hypertonic medium with $150 \mathrm{mM}$ sucrose in the presence of DD for $2 \mathrm{~h}$ formed a single band, as did 


\begin{tabular}{|c|c|c|c|c|c|c|}
\hline \multirow{2}{*}{$\begin{array}{c}\text { Media } \\
\text { Incubation time }\end{array}$} & \multicolumn{3}{|c|}{ RPMI + $200 \mathrm{mM}$ sucrose } & \multicolumn{3}{|c|}{ RPMI + $300 \mathrm{mM}$ sucrose } \\
\hline & $0.5 \mathrm{~h}$ & $2 \mathrm{~h}$ & $\begin{array}{c}\text { Difference } \\
0.5-2 \mathrm{~h}\end{array}$ & $0.5 \mathrm{~h}$ & $2 \mathrm{~h}$ & $\begin{array}{c}\text { Difference } \\
0.5-2 \mathrm{~h}\end{array}$ \\
\hline $\mathrm{K}^{+}$ & $731 \pm 17$ (5) & $790 \pm 16(21)$ & $59 *$ & $756 \pm 29(8)$ & $880 \pm 30(8)$ & $124^{*}$ \\
\hline $\mathrm{Na}^{+}$ & $239 \pm 12(3)$ & $259 \pm 16(17)$ & 20 & $167 \pm 12(9)$ & $168 \pm 13(9)$ & 1 \\
\hline $\mathrm{Cl}^{-}$ & $272 \pm 13(12)$ & $368 \pm 18(12)$ & $96^{*}$ & n.d. & n.d. & n.d. \\
\hline Water & $2.93 \pm 0.07(4)$ & $3.30 \pm 0.03(7)$ & 0.37 & $2.31 \pm 0.02(3)$ & $2.71 \pm 0.02(3)$ & 0.40 \\
\hline Total osmolytes & 1494 & 1683 & 189 & 1409 & 1653 & 244 \\
\hline
\end{tabular}

Table 1. Changes in ion and water content associated with RVI in U937 cells incubated in hypertonic media with 200 and $300 \mathrm{mM}$ sucrose. Means \pm SEM (number of determinations in parentheses) of values combined from the measurements on fractionated and whole populations (which is acceptable owing to the negligible proportion of $\mathrm{H}$ cells during the first two hours of incubation). Ion and osmolyte content is provided in $\mu$ mol per $g$ of cell protein, and cell water expressed in ml per $g$ of cell protein. Total content of cell osmolytes was calculated by multiplying the water content by the osmolarity of the external medium. The value of $\mathrm{Cl}^{-}$content at time point $0.5 \mathrm{~h}$ was taken equal to its value at time zero. ${ }^{*}(\mathrm{P}<0.03)$ indicates statistical significance

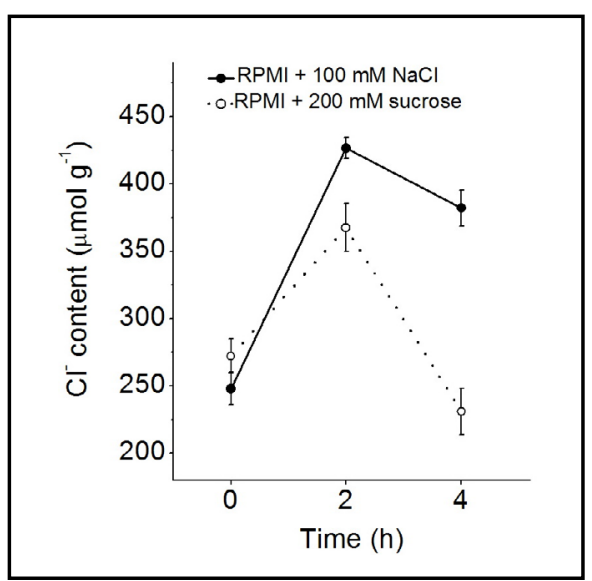

Fig. 2. Changes in intracellular $\mathrm{Cl}^{-}$content caused by hypertonicity. The data at time zero correspond to cells in isotonic RPMI medium. The measurements were done on cells that were not fractionated in Percoll. The values represent the means \pm SEM based on 3-5 independent experiments.

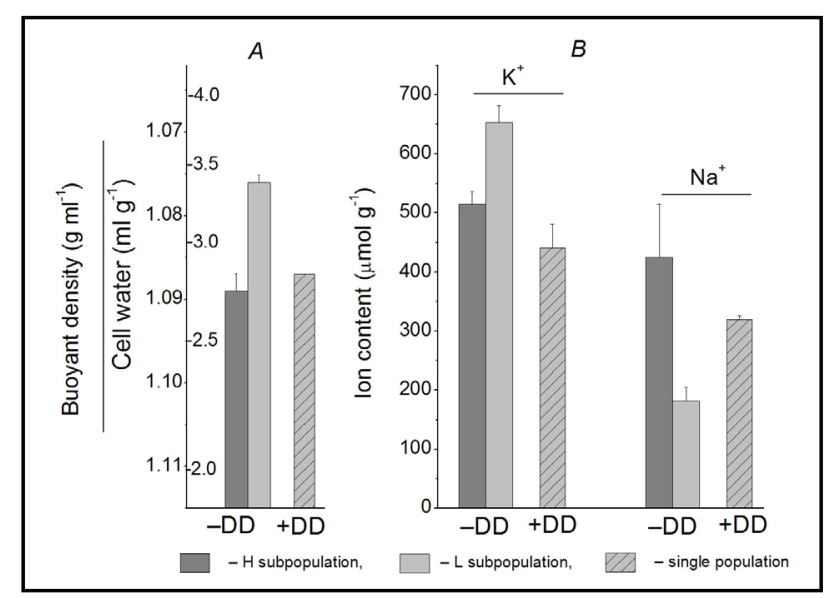

Fig. 3. Effect of DMA+DIDS (DD) on cell buoyant density, cell water and $\mathrm{K}^{+} / \mathrm{Na}^{+}$content. Cells were incubated in RPMI+150 mM sucrose for $2 \mathrm{~h}$; DMA (0.05 mM) and DIDS $(0.5 \mathrm{mM})$ were added simultaneously with sucrose. The means \pm SEM are shown for 3 (-DD) or 2 (+DD) experiments.

untreated cells following $0.5 \mathrm{~h}$ incubation in hypertonic medium without blockers. The cell density in this band was similar to the density of the $\mathrm{H}$ fraction in the absence of DD. Thus DD abolished both the changes in cell density and in intracellular $\mathrm{K}^{+}$content associated with RVI (Fig. 3B). The currently accepted model holds that RVI starts with $\mathrm{Na}^{+}$entry and the accumulated $\mathrm{Na}^{+}$is exchanged thereafter for $\mathrm{K}^{+}$via the $\mathrm{Na}^{+} / \mathrm{K}^{+}$pump $[35,38]$. This scheme seems to be applicable to U937 cells. It should be noted that no consistent increase in $\mathrm{Na}^{+}$ content was observed during the time interval $0.5-2 \mathrm{~h}$, whereas the increase in $\mathrm{K}^{+}$content was significant (Fig. 1E-H, Table 1). Interestingly, DD abolished the decrease in $\mathrm{Na}^{+}$content in cells of the L subpopulation relative to that in $\mathrm{H}$ cells, as shown in Fig. 3. No more than a slight effect of DD on the cell buoyant density and the monovalent cation content was found in U937 cells incubated in standard normotonic RPMI medium (data not shown). The NKCC inhibitor, $50 \mu \mathrm{M}$ bumetanide, was without effect on the RVI in our experiments.

The long-term cell shrinkage seen as a slowly increasing cell density reflected AVD. As shown earlier apoptosis of U937 cells induced by staurosporine is characterized not only by a decrease in cell density and $\mathrm{K}^{+}$content but also by inhibition of the sodium pump, i.e. by a decrease in ouabain-sensitive $\mathrm{Rb}^{+}$influx $[26,29,30,39]$. A similar decrease in ouabain- 


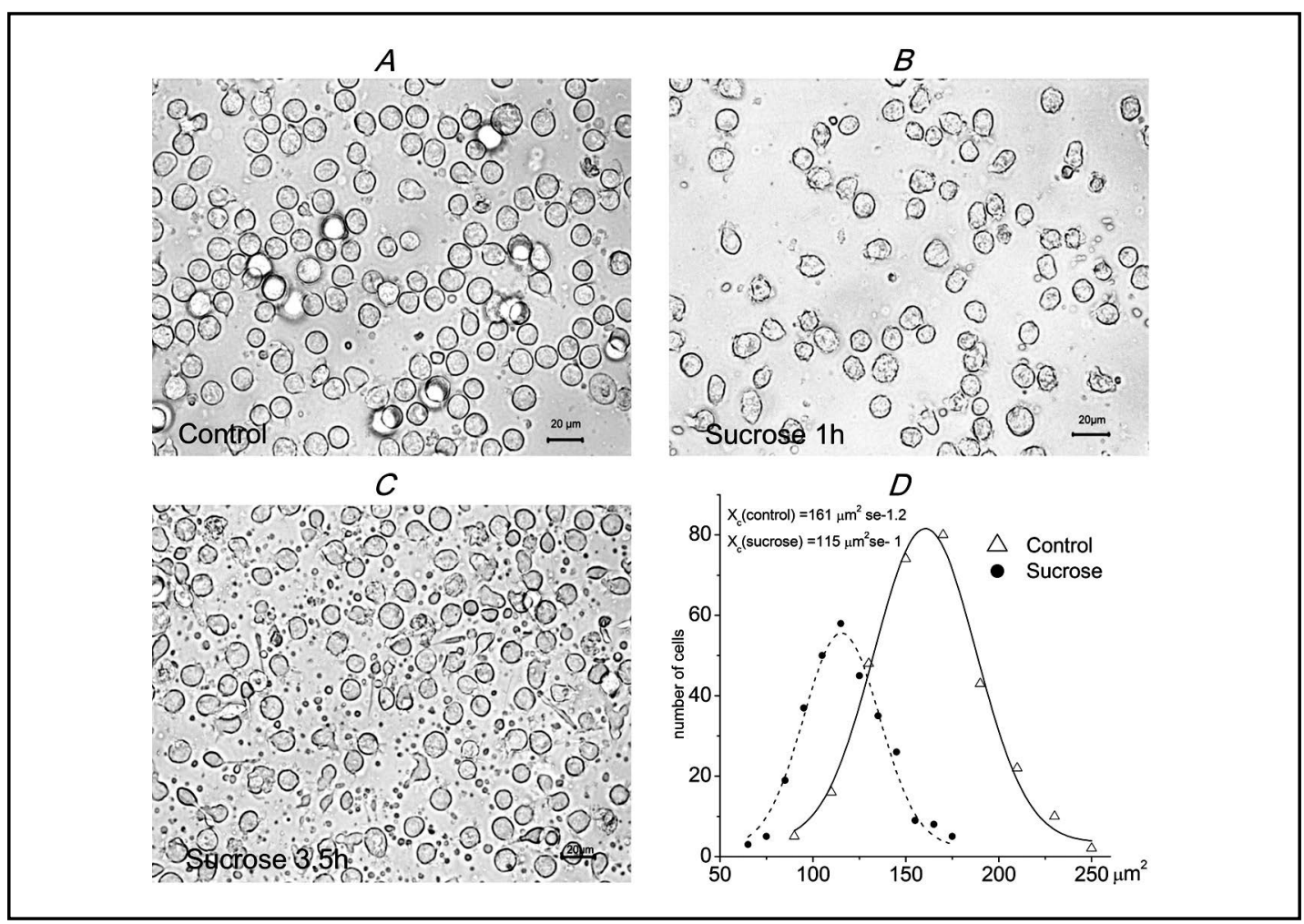

Fig. 4. Microscopy and morphometry of U937 cells before and following incubation in hypertonic media with $200 \mathrm{mM}$ sucrose. (A-C), Images of cells in culture plates following 1 and $3.5 \mathrm{~h}$ incubation. (D), distribution of cells by the area for $0.5 \mathrm{~h}$ incubation.

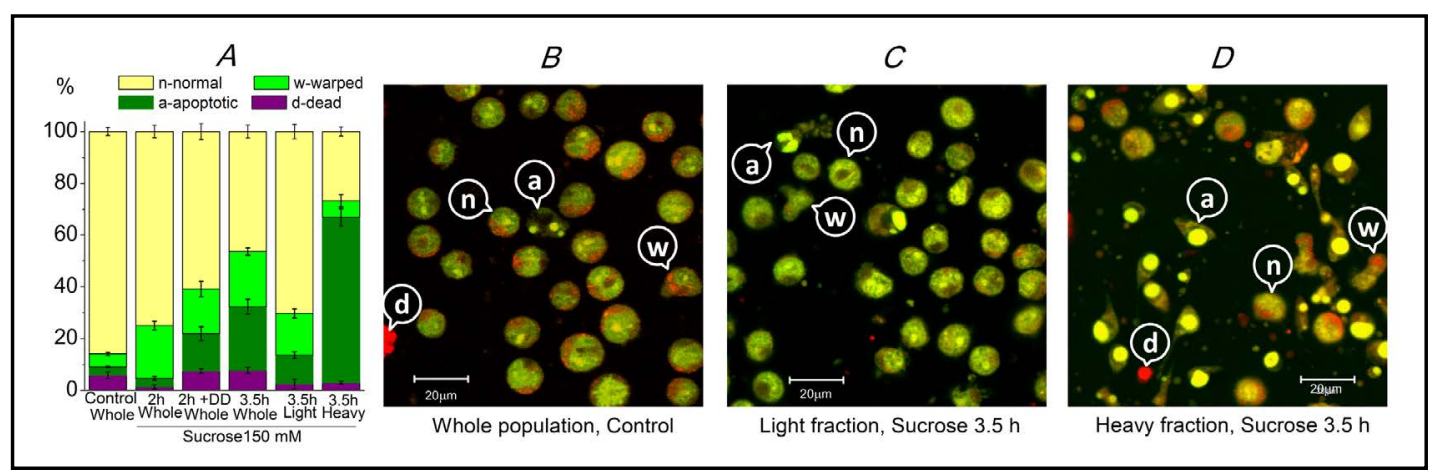

Fig. 5. Cell morphology in light and heavy fractions of U937 cells collected from Percoll density gradient after 2 and $3 \mathrm{~h}$ incubation in hypertonic media with $150 \mathrm{mM}$ sucrose. (A) Percentage of cells of different types. Warped cells were discriminated by having roundness less than 0.8 (round is shape descriptor in results menu of Image $1.43 \mathrm{u}$ ). Means \pm SEM for 5-10 microscopic fields obtained in 1-2 separate experiments and a total of about 200-300 cells. $(B-D)$ Fluorescent images of cells stained by AO (green, orange in electronic version) and EB (red in electronic version) acquired on a Leica TCS SL confocal microscope.

sensitive $\mathrm{Rb}^{+}$influx was observed in $\mathrm{H}$ subpopulation of $\mathrm{U} 937$ cells incubated for sufficiently long time in hypertonic media (Fig. 1I-K).

\section{Microscopy}

Under transmission or fluorescent microscope intact U937 cells appeared as a uniform population of relatively round cells (Fig. $4 A$ ). During the first $0.5-1 \mathrm{~h}$ of incubation in hypertonic media, the cell morphology remained unchanged (Fig. 4B). Strong initial osmotic 
shrinkage of round cells placed in a hypertonic solution was revealed by morphometric analysis (Fig. 4D). However, minor changes in cell size associated with RVI and AVD were difficult to analyze by this method (Fig. 4C).

Long-term morphological alteration of cells in hypertonic media occurred asynchronously, and the cell population turned out to be heterogeneous. At least four morphologically distinct types present in all populations could be identified. Examples of these variants are marked in Fig. 5 as normal $(n)$, warped without chromatin condensation $(w)$, apoptotic with condensed chromatin $(a)$, and EB-positive, or dead $(d)$.

Fig. $5 A$ shows changes in the percentage of cells of different types following 2 and 3 $\mathrm{h}$ incubation in hypertonic RPMI media with $150 \mathrm{mM}$ sucrose. A similar time course of morphological changes, but on a different time scale, was observed in hypertonic media with 200 and $300 \mathrm{mM}$ sucrose, as well as with $100 \mathrm{mM} \mathrm{NaCl}$ (images are not shown).

Most importantly, the subpopulation of heavy cells separated in Percoll density gradient, H-subpopulation, contained predominantly cells with condensed chromatin, which is a highly specific marker of apoptosis. This can be seen in Fig. $5 A$ by comparing proportions of different cells following $3 \mathrm{~h}$ incubation in $\mathrm{H}$ and $\mathrm{L}$ subpopulations. Cell shrinkage and chromatin condensation occurred in parallel, supporting the assumption that long-term shrinkage of U937 cells treated with hypertonic solution reflects AVD. Cells with condensed chromatin often, but not always, lost their round shapes. Warped cells did not exhibit chromatin condensation (Fig. $5 B-D$ ). Interestingly, the number of the warped cells increased in the $\mathrm{L}$ subpopulation and decreased in the $\mathrm{H}$ subpopulation inversely to changes in the fraction of apoptotic cells with condensed chromatin (Fig. 5A). Most of the cells in $\mathrm{L}$ subpopulation were round and resembled untreated cells (Fig. 5C). Changes in relative numbers of different cell types in samples treated with DD (not shown) confirmed that in this case the percentage of apoptotic cells is increased due to the absence of the L population.

\section{Discussion}

As shown in a wide variety of cells employing a variety of experimental approaches, hypertonic stress causes apoptosis [1, 2, 4-18]. It is widely agreed that AVD is one of the hallmarks of apoptosis that precedes other apoptotic markers, e.g. caspase activation, cytochrome c release from mitochondria, DNA fragmentation and chromatin condensation $[19-25,27,40]$. Long-term volume decrease after the initial apoptotic shrinkage was found in Ehrlich ascites cells placed in a hypertonic medium [41, 42]. This effect may be interpreted as the AVD response. A decrease in HL-60 cell volume relative to the initial value following $8 \mathrm{~h}$ incubation in a hypertonic medium with $300 \mathrm{mM}$ mannitol has also been reported [13]. Changes in the cell volume of apoptotic human glioblastoma D54-MG caused by various inducers, including hypertonic medium with $300 \mathrm{mM}$ mannitol were reported by Ernest et al. [16].

The RVI response to hypertonic cell shrinkage is a well studied phenomenon $[12,27$, $37,43-46]$. The magnitude of the initial cell shrinkage and the subsequent volume increase found in our experiments with U937 cells by using cell density measurement are of the same order of magnitude as reported for other cells using the Coulter electronic sizer and other methods. Our data show that U937 cells respond to hypertonic shrinkage without preliminary incubation in hypotonic media. RVI in U937 cells was associated with the increase in intracellular $\mathrm{K}^{+}$rather than $\mathrm{Na}^{+}$content. This contrasts the $\mathrm{Na}^{+}$increase reported for RVI in HeLa cells [47]. We have also observed that inhibition of $\mathrm{Na}^{+} / \mathrm{H}^{+}$and $\mathrm{Cl}^{-} / \mathrm{HCO}_{3}^{-}$ exchangers or HICC channels abolishes RVI in U937 cells, as it does in many other cell types [27]. The long-term decrease of the cell volume following the initial RVI in hypertonic media may have gone unnoticed in previous studies probably because the experiments were not carried out long enough. By extending observation time to 2-4 h we were able to detect the transition from RVI to AVD in U937 cells. Thus, U937 cells appear to be a useful model to study the switch of cellular volume regulation from RVI to AVD. 
The relationship between RVI and AVD was studied in detail in HeLa cells treated by various combinations of hypertonicity and traditional apoptosis inducers, such as staurosporine, TNF-alpha, FasL etc [47-50]. It was shown, in particular, that suppression of RVI in HeLa cells by HICC, NHE and $\mathrm{Cl}^{-} / \mathrm{HCO}_{3}^{-}$blockers leads to AVD following hypertonic shrinkage [48]. The conclusion made from these studies was that dysfunction of RVI is a prerequisite for the induction of apoptosis.

Our experiments showed that apoptosis may develop in cells that were initially capable of the RVI response; eventually, RVI gave way to AVD. Therefore, it is not the lack of RVI that triggers apoptosis (accompanied by AVD at a certain stage). Obviously, RVI and AVD cannot be taking place at the same time; it is likely that hypertonic stress initiates both RVI and AVD, but the latter develops slower and becomes detectable at a relatively late stage. The molecular mechanisms underlying the "tug-of-war" between AVD and RVI in HeLa cells have been reported recently by Subramanyam et al. [47], and similar considerations may apply to U937 cells.

With regard to the interplay between RVI and apoptosis, two possibilities should be considered. The first one is that hypertonicity-induced apoptosis becomes possible only when RVI fails for some reason, thus enabling cell shrinkage. This scenario implies that AVD (either by itself or via accompanying ion changes) serves as the signal that launches apoptosis. The second possibility is that both apoptosis and RVI are independently activated by hypertonic stress, but AVD becomes apparent only at a late stage, when shrinkage overrides the effect of RVI. Admittedly, the results of our study do not allow to unequivocally deciding between these two possibilities, but we lean toward the second one. While in some systems AVD has been shown to be a strict requirement for apoptosis [23, 47], in other cases apoptosis can proceed without any shrinkage [29,51]. Even a transient swelling during early stages of apoptosis has been reported recently [52]. On the other hand, persistent swelling does not seem to be compatible with apoptosis, but is rather a signature of necrotic cell death, leading to plasma membrane rupture with subsequent tissue inflammation. Accordingly, AVD may be viewed as an evolutionary mechanism to prevent swelling and leakage of intracellular components from damaged cells.

\section{Acknowledgements}

This study was supported by the Russian Foundation for Basic Research, projects no. 12-04-01669-a, by the Program of Presidium RAS, project "Coordination of monovalent ion fluxes in regulation of ion and water balance in animal cells", and by the Deutsche Forschungsgemeinschaft (436 RUS 113/488/0-2R, RFBR 06-04-04000). The authors acknowledge the meticulous preparation of the manuscript by Lejla Subasic.

\section{References}

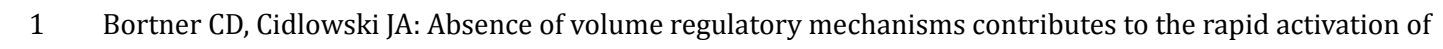
apoptosis in thymocytes. Am J Physiol 1996;271:C950-C961.

2 Bortner CD, Cidlowski JA: Life and death of lymphocytes: a volume regulation affair. Cell Physiol Biochem 2011;28:1079-1088.

3 Bortner CD, Scoltock AB, Sifre MI, Cidlowski JA: Osmotic stress resistance imparts acquired anti-apoptotic mechanisms in lymphocytes. J Biol Chem 2012;287:6284-6295.

4 Edwards YS, Sutherland LM, Power JH, Nicholas TE, Murray AW: Osmotic stress induces both secretion and apoptosis in rat alveolar type II cells. Am J Physiol Lung Cell Mol Physiol 1998;275:L670-L678.

5 Michea L, Ferguson DR, Peters EM, Andrews PM, Kirby MR, Burg MB: Cell cycle delay and apoptosis are induced by high salt and urea in renal medullary cells. Am J Physiol Renal Physiol 2000;278:F209-F218. 
Yurinskaya/Moshkov/Wibberley et al.: Apoptotic and Volume Regulatory Response of Cell to Hypertony

6 Terada Y, Inoshita S, Hanada S, Shimamura H, Kuwahara M, Ogawa W, Kasuga M, Sasaki S, Marumo F: Hyperosmolality activates Akt and regulates apoptosis in renal tubular cells. Kidney Int 2001;60:553-567.

7 Lang KS, Fillon S, Schneider D, Rammensee HG, Lang F: Stimulation of TNF alpha expression by hyperosmotic stress. Pflügers Arch 2002;443:798-803.

8 Lang F, Gulbins E, Lang PA, Zappulla D, Föller M: Ceramide in suicidal death of erythrocytes. Cell Physiol Biochem 2010;26:21-28.

-9 Reinehr R, Graf D, Fischer R, Schliess F, Häussinger D: Hyperosmolarity triggers CD95 membrane trafficking and sensitizes rat hepatocytes toward CD95L-Induced apoptosis. Hepatology 2002;36:602-614.

10 Copp J, Wiley S, Ward MW, Van der Geer P: Hypertonic shock inhibits growth factor receptor signaling, induces caspase- 3 activation, and causes reversible fragmentation of the mitochondrial network. Am J Physiol Cell Physiol 2005;288:C403-C415.

-11 Friis MB, Friborg CR, Schneider L, Nielsen MB, Lambert IH, Christensen S, Hoffmann E: Cell shrinkage as a signal to apoptosis in NIH 3T3 fibroblasts. J Physiol 2005;567:427-443.

12 Burg MB, Ferraris JD, Dmitrieva NI: Cellular response to hyperosmotic stresses. Physiol Rev 2007;87:14411474.

13 Ghosh A, Keng PC, Knauf PA: Hypertonicity induced apoptosis in HL-60 cells in the presence of intracellular potassium. Apoptosis 2007;12:1281-1288.

14 Racz B, Reglodi D, Fodor B, Gasz B, Lubics A, Gallyas F, Roth E Borsiczky B: Hyperosmotic stress-induced apoptotic signaling pathways in chondrocytes. Bone 2007;40:1536-1543.

15 Reinehr R, Häussinger D: Hyperosmotic activation of the CD95 system. Methods Enzymol 2007;428:145160.

16 Ernest NJ, Habela CW, Sontheimer H: Cytoplasmic condensation is both necessary and sufficient to induce apoptotic cell death. J Cell Sci 2008;121:290-297.

-17 Häussinger D, Reinehr R: Osmotic regulation of bile acid transport, apoptosis and proliferation in rat liver. Cell Physiol Biochem 2011;28:1089-1098.

18 Hoffmann EK: Ion channels involved in cell volume regulation: effects on migration, proliferation, and programmed cell death in non adherent EAT cells and adherent ELA cells. Cell Physiol Biochem 2011;28:1061-1078.

19 Bortner CD, Cidlowski JA: A necessary role for cell shrinkage in apoptosis. Biochem Pharmacol 1998;56:1549-1559.

20 Bortner CD, Cidlowski JA: Cell shrinkage and monovalent cation fluxes: role in apoptosis. Arch Biochem Biophys 2007;462:176-188.

21 Lang F, Busch GL, Ritter M, Völkl H, Waldegger S, Gulbins E, Häussinger D: Functional significance of cell volume regulatory mechanisms. Physiol Rev 1998;78:247-306.

22 Lang F, Föller M, Lang K, Lang P, Ritter M, Vereninov A, Szabo I, Huber SM, Gulbins E: Cell volume regulatory ion channels in cell proliferation and cell death. Methods Enzymol 2007;428:209-225.

23 Maeno E, Ishizaki Y, Kanaseki T, Hazama A, Okada Y: Normotonic cell shrinkage because of disordered volume regulation is an early prerequisite to apoptosis. Proc Nat Acad Sci USA 2000;97:9487-9492.

24 Okada Y, Maeno E, Shimizu T, Dezaki K, Wang J, Morishima S: Receptor-mediated control of regulatory volume decrease (RVD) and apoptotic volume decrease (AVD). J Physiol 2001;532:3-16.

-25 Shimizu T, Maeno E, Okada Y: Prerequisite role of persistent cell shrinkage in apoptosis of human epithelial cells. Acta Physiol Sinica 2007;59:512-516.

-26 Yurinskaya VE, Rubashkin AA, Vereninov AA: Balance of unidirectional monovalent ion fluxes in cells undergoing apoptosis: why does $\mathrm{Na}^{+} / \mathrm{K}^{+}$pump suppression not cause cell swelling? J Physiol 2011;589:2197-2211.

27 Hoffmann EK, Lambert IH, Pedersen SF: Physiology of cell volume regulation in vertebrates. Physiol Rev 2009;89:193-277.

28 Yurinskaya VE, Rubashkin AA, Shirokova AV, Vereninov AA: Regulatory Volume Increase (RVI) and Apoptotic Volume Decrease (AVD) in U937 Cells in Hypertonic Medium. Cell and Tissue Biology 2011;5:487-494.

29 Yurinskaya V, Goryachaya T, Guzhova I, Moshkov A, Rozanov Y, Sakuta G, Shirokova A, Shumilina E, Vassilieva I, Lang F, Vereninov A: Potassium and sodium balance in U937 cells during apoptosis with and without cell shrinkage. Cell Physiol Biochem 2005;16:155-162. 
Yurinskaya/Moshkov/Wibberley et al.: Apoptotic and Volume Regulatory Response of Cell to Hypertony

-30 Vereninov AA, Rubashkin AA, Goryachaya TS, Moshkov AV, Rozanov YM, Shirokova AV, Strelkova EG, Lang F, Yurinskaya VE: Pump and channel $\mathrm{K}\left(\mathrm{Rb}^{+}\right)$fluxes in apoptosis of human lymphoid cell line U937. Cell Physiol Biochem 2008;22:187-194.

-31 Hoffmann EK, Simonsen LO: Membrane mechanisms in volume and pH regulation in vertebrate cells. Physiol Rev 1989;69:315-382.

32 Ernest NJ, Sontheimer H: Extracellular glutamine is a critical modulator for regulatory volume increase in human glioma cells. Brain Res 2007;1144:231-238.

33 Hughes AL, Pakhomova A, Brown PD: Regulatory volume increase in epithelial cells isolated from the mouse fourth ventricle choroid plexus involves $\mathrm{Na}^{+}-\mathrm{H}^{+}$exchange but not $\mathrm{Na}^{+}-\mathrm{K}^{+}-2 \mathrm{Cl}^{-}$cotransport. Brain Research 2010;1323:1-10.

-34 Pedersen SF, Kramhøft B, Jorgensen NK, Hoffmann EK: Shrinkage-induced activation of the $\mathrm{Na}^{+} / \mathrm{H}^{+}$ exchanger in Ehrlich ascites tumor cells: mechanisms involved in the activation and a role for the exchanger in cell volume regulation. J Membr Biol 1996;149:141-159.

35 Wehner $\mathrm{F}$, Tinel $\mathrm{H}$ : Role of $\mathrm{Na}^{+}$conductance, $\mathrm{Na}^{+}-\mathrm{H}^{+}$exchange, and $\mathrm{Na}^{+}-\mathrm{K}^{+}-2 \mathrm{Cl}$ symport in the regulatory volume increase of rat hepatocytes. J Physiol 1998;506:127-142.

36 Gamper N, Huber SM, Badawi K, Lang F: Cell volume-sensitive sodium channels upregulated by glucocorticoids in U937 macrophages. Pflügers Arch 2000;441:281-286.

-37 Wehner F, Bondarava M, ter Veld F, Endl E, Nürnberger H, Li T: Hypertonicity-induced cation channels. Acta Physiol 2006;187:21-25.

38 Wehner F, Tinel $\mathrm{H}$ : Osmolyte and $\mathrm{Na}^{+}$transport balances of rat hepatocytes as a function of hypertonic stress. Pflügers Arch 2000;441:12-24.

39 Vereninov AA, Goryachaya TS, Moshkov AV, Vassilieva IO, Yurinskaya VE, Lang F, Rubashkin AA: Analysis of the monovalent ion fluxes in U937 cells under the balanced ion distribution: recognition of ion transporters responsible for changes in cell ion and water balance during apoptosis. Cell Biol Int 2007;31:382-393.

40 Bortner CD, Cidlowski JA: The role of apoptotic volume decrease and ionic homeostasis in the activation and repression of apoptosis. Pflügers Arch 2004;448:313-318.

-41 Hendil KB, Hoffmann EK: Cell volume regulation in Ehrlich ascites tumor cells. J Cell Physiol 1974;84:115125.

42 Levinson C: Inability of Ehrlich ascites tumor cells to volume regulate following a hyperosmotic challenge. J Membr Biol 1991;121:279-288.

-43 O’Neill W: Physiological significance of volume-regulatory transporters. Am J Physiol Cell Physiol 1999;276:C995-C1011.

-44 Wehner F, Olsen H, Tinel H, Kinne-Saffran E, Kinne RK: Cell volume regulation: osmolytes, osmolyte transport, and signal transduction. Rev Physiol Biochem Pharmacol 2003;148:1-80.

45 Lambert IH, Hansen DB: Regulation of taurine transport systems by protein kinase CK2 in mammalian cells. Cell Physiol Biochem 2011;28:1099-1110.

-46 Lewis R, Feetham CH, Barrett-Jolley R: Cell volume regulation in chondrocytes. Cell Physiol Biochem 2011;28:1111-1122.

-47 Subramanyam M, Takahashi N, Hasegawa Y, Mohri T, Okada Y: Inhibition of protein kinase Akt1 by apoptosis signal-regulating kinase-1 (ASK1) is involved in apoptotic inhibition of regulatory volume increase. J Biol Chem 2010;285:6109-6117.

48 Maeno E, Takahashi N, Okada Y: Dysfunction of regulatory volume increase is a key component of apoptosis. FEBS Lett 2006;580:6513-6517.

49 Shimizu T, Wehner F, Okada Y: Inhibition of hypertonicity-induced cation channels sensitizes HeLa cells to shrinkage-induced apoptosis. Cell Physiol Biochem 2006;18:295-302.

50 Numata T, Sato K, Okada Y, Wehner F: Hypertonicity-induced cation channels rescue cells from staurosporine-elicited apoptosis. Apoptosis 2008;13:895-903.

51 Bortner CD, Cidlowski JA: Uncoupling cell shrinkage from apoptosis reveals that $\mathrm{Na}^{+}$influx is required for volume loss during programmed cell death. J Biol Chem 2003;278:39176-39184.

52 Platonova A, Koltsova SV, Hamet P, Grygorczyk R, Orlov SN: Swelling rather than shrinkage precedes

apoptosis in serum-deprived vascular smooth muscle cells. Apoptosis 2012;17:429-438. 